\title{
Important TQM Implementation Contributors in Pakistani Petrochemical Sector
}

\author{
Yasir Latif \\ Institute of Business and Management (IB\&M) \\ University of Engineering and Technology, Lahore, Pakistan \\ mianyasirlatif@gmail.com \\ Muhammad Fiaz \\ Institute of Business and Management (IB\&M), \\ University of Engineering and Technology, Lahore, Pakistan \\ fiaz0128@gmail.com \\ Muhammad Shoaib \\ Institute of Business and Management (IB\&M), \\ University of Engineering and Technology, Lahore, Pakistan \\ shoaib@uet.edu.pk
}

\begin{abstract}
This study discusses quality practices in Pakistani Petrochemical sector to understand TQM practices and their implementation in Pakistan. It helps to understand the role of leadership, vision \& plan statement, employee participation and education \& training as important constructs of TQM. It shows how these constructs help to speed up the TQM implementation in petrochemical sector like other constructs of TQM and finally company moves towards quality approach. The responses of executives, managerial staff and workers were received using questionnaire and online surveys which are sent through Google Drive. Data of 106 respondents was taken in this study and analyzed by SPSS18. Study shows that Total Quality Management culture is less understood by employees, thus less adopted and implemented in Pakistan. Petrochemical companies fail to adopt the TQM philosophy and processes, hence reducing productivity and profits. This research paper is very helpful for executives for TQM implementation in petrochemical sector.
\end{abstract}

Keywords: Education, Implementation, Leadership, Petrochemical, Pakistan, TQM.

\section{Introduction}

Total quality management is a way followed by many firms to increase their productivity and operational conformance. People believe that by implementing TQM, the efficiency, effectiveness and productivity of organizations can be enhanced (Zhang et al. 2000). Quality management implementation is the way by which activities can be carried on in conformance of planning. It is seen that those companies which are more concerned about effective TQM implementation it in their organization in accordance to financial constraints, usually takes more pie of market share than other companies (Abdallah 2013) (Terziovski et al. 2003). The excellence in the form of quality of products or services can help the organizations for the achieving more market share (Deming 1986). TQM is a mitigated philosophy as it is not based on well set guided principles (Hackman et al. 1995). Human beings are increasingly dominant part of successful TQM implementation (Brah et al. 1985). Employee participation is very important constituent of TQM 
implementation. The more interaction, support, help mutual assistance and appreciation on achievement from organization will lead to better TQM implementation (Mann et al. 1995). The firms that take interest in consistent growth, customer friendly behavior, enhancing employee's morale, perform better than those which don't do so (Zhou et al. 2001). Leaders are normally attributed with 7 attributes: drive, motivation, honesty \& integrity, confident personality, analytical and cognitive thinking ability, businesses know how and charismatic personality (Deming 1986). A leader is always associated with a clear vision and plan (Chen 1997). For TQM implementation, there is always a need of leader because leader can create a vision and with that vision statement he can generate his influence on the entire organization and employees (Kotter, J.P. 1995). There is a need of employee participation to have an effective change in their behavior. This employee involvement tends to increase their quality perspectives (Juran and Gryna 1993). If an organization wants to flourish itself and equip with TQM then it has to work on employee education and training (Mann et al. 1993). The above discussion puts more emphasis on Leadership as compared to vision and plan statement, employee participation and education and training. However, there seems a need to probe in and study if the same analogy is workable in Petrochemical Sector of Pakistan. The investigation through study shows such results in next parts of study.

\section{Constructs for manifestation of TQM culture}

TQM Gurus like Juran, Deming, Gryna, Crosby, Ishikawa, Feigenbaum etc. are the main reason of the new heights of the TQM thinking. They have provided simple rules, by following which the production mechanism can be made better, the cost of production can be reduced, non-conformities can be avoided, increasingly improved salient features can be developed, continuous improvement can be achieved and financial benefits can be reached (Anderson et al. 1999). These are not just the words of mouth, organization like Toyota, Motorola, Honda, Dabba-Wala etc. have actually achieved it. Deming, Juran and Gryna, Ishikawa, Feigenbaum and many more are heroes for this new world, the TQM world. Different countries introduced many awards for leading continuous improving companies such as "Deming award, Malcolm Baldridge National Quality Award and European Quality Award. These awards create a thirst of performing at a better pace for a defined purpose, being the best producer who exceeds the desired and expectations. Following "An Instrument for Measuring TQM Implementation for Chinese Manufacturing Companies" by Zhai Zhang, Ab Waszink and Jacob Wijngaard 2000, an effort is carried out to implement some of constructs to Petrochemical Sector of Pakistan other constructs will be treated in further studies.

\section{Leadership}

Leadership is a relationship through which one individual impacts the behavior or activities of other individuals (Mullins 1996). TQM implementation is not a simple task. It requires a lot of determination, documentation, rescheduling, changed working requirements, external assessment pressures, quality improvements, and ongoing huge list of requirements to be met (Chin et al. 2001). This explains the need of motivation and why leadership is important? What can leaders do for TQM implementation is an arising 
question for Petrochemical Sector? On the basis of literature review, Leadership means a group of collaborating senior executives that has devoted itself for external customers contentment, vision and mission dissemination to workers to align them on a united achievement motive in Petroleum sector. It is seen that leaders are the one of the source of organization commitment, motivation, quality initiatives, organizational citizenship behavior, long term quality plans, minimize the resistance to change and provides operational learning of internal customers of organization (Ehigie et al. 2004). Crosby concluded that TQM is helpful for improved resilience of senior executives and they should treat quality as their dominant responsibility. Leadership is an important part of TQM implementation because it gives the source of proper orientation, implementation and origin of whole quality activities (Prajogo et al. 2004) (Singh 2006) (Saravanan R. 2007) (Teh 2008) (Sit 2009) (Teh 2009) (Fotopoulos 2009). Dale has also same thinking for senior management that they are the key initiators of Quality revolution which is termed as second industrial revolution by Kanji. For TQM, the employee and leadership participation is most determinant concepts (Prasad et al. 2003). In petroleum sector motivation level and organization citizenship is fluctuating among the employees of different companies. It is also very different among different departments of every company because of fluctuating returns, new opportunities, and constant threat of job loss even when it is not more than $1 \%$ of business cost etc. These conditions are very alarming so there should be a key role from management and leadership side to keep high the morale of employees.

\section{Vision and Plan Statement}

Vision statement explains what one wants to be in the eyes of people in future in a specific business line. Vision is a broader picture of the real essence of business. It is survival of the principles, believes and moral values dipped in the trueness of business, loosely speaking it is reason of being. When vision is departmentalized in the form of departmental goals then it is defining the goals of the departments to support the accomplishment of vision. These departmental goals are plans or missions (Rahman 2004). Mission statement identifies the small plans which support the reason of being of business in an industry. Therefore, there is a strong relationship among the vision statement, mission statement for better achievement of quality goals (Gadenne et al. 2009). The plan statement thus supports the departments and finally these departments' missions support the mission statement. Vision should be communicated to everyone in the company both vertically and horizontally. However, the Mission statement dissemination depends as per policy of departments. The vision and mission statements are mitigated and generally treated as something similar in Petrochemical Sector of Pakistan which is not appropriate. Even If the two statements are present, still these are not well communicated and disseminated in most of companies.

\section{Employees Participation}

The employees are the key elements who a play deterministic role in quality development activities (Zairi et al. 1994) (Wilkinson et al. 1998) (Vouzas et al. 2005) (Tsang et al. 2000) (Samson et al. 1999). The employees are required to adopt quality thinking mind, new set of approach, alter their current patterns through change and alleviation of negative attitudes for TQM implementation. Furthermore, employees can contribute to 
extend the quality movement to all departments of the organization. There are a lot of benefits of employee participation, it can impart new sources of knowledge, understanding of TQM benefits, can do approach, developed personal abilities and self esteem, overcoming the negative attitudes, contentment, trust on their performance, easy accountability, can report operational issues and documented secured background. The employees can perform better in the presence of quality circles, team and group formations, cross functional efforts, volunteer associations, ideas and information sharing (Rahman et al. 2005). The ideas from employees' side must be accounted for because they are facing the actual work problems and can advise better treatments (Prajogo et al. 2004). This will lead reduction of problems and more value addition. Employee's contribution is decider for better quality (Powel 1995). TQM approach is in growing stage as employees are ordered to improve quality but the executives refrain to ask the problems of the workers and to take initiatives n Petrochemical companies.

\section{Education and Training}

Education is the source of development in any organization. Better the sources of education system in an organization, better will be the outputs in terms of quality. It is so, because both i.e. sources of education and output quality, have strong relationship. Studies have proved that education and training are the strong constituents of TQM implementation. Companies normally focus on competitive benchmarking to improve their production and to attain better products (Abdullah et al. 2008) (Dessler 2003). They don't go for product innovation and process innovation because Research and Development R\&D system is poor in country and still in an emerging stage. Executives don't invest on education and training of the employees in most of companies because they focus on continuous return avoiding taking risks for the education and training of employees. The prevailing trend is "on job training", making mistakes and learning from these. But the problem is it costs more and companies have to face heavy losses even in human capital.

\section{Research Methodology}

This research is to check the relative effect of four important TQM contributors and to find out the contributor that is the more deterministic in TQM implementation. Researcher has used the instrument named as "An Instrument for measuring TQM Implementation in Chinese manufacturing Companies". It is a quantitative research study in which 4 constructs out of 11 constructs are taken to check whether these can be implemented in Petrochemical sector in Pakistan. Time shortage is basic reason to take only four constructs out of eleven. The literature review suggests that these constructs (leadership, vision and plan statement, employee participation and education and training) are essentials for TQM implementation. The instrument has 137 citations in various research articles and was first published in "International Journal of Quality and Reliability Management". The instrument uses five options Likert's scale. It requires the respondent to rate his opinion between strongly disagree to strongly agree. Questionnaires were served to 106 respondents of Petrochemical companies of Pakistan which included both the employees and senior executives. Responses were also recorded using Google Drive application. Total 136 questionnaires were served, out of which 106 were received with $77.94 \%$ response rate. The responses were taken from leading 
petrochemical companies with more than 100 employees each and run through SPSS18. Each construct had a reliability coefficient of Cronbach's alpha above 0.70 and was thus found reliable. Since the instrument has 137 citations, it warrants no Exploratory Factor Analysis (EFA) and Confirmatory Factor Analysis (CFA). It was found through Regression that all the constructs have statistically significant relationship with TQM implementation. The theoretical framework is given in the figure 1 where the four constructs i.e. Leadership, Vision and Plan Statement, Employee Participation and Education and Training is computed through their respective dimensions i.e. Leadership is computed through Dimension like L1, L2,.... L7, L8. Similarly other constructs are also computed in similar way. All these constructs are finally computing Total Quality Management (TQM).

\begin{tabular}{|c|c|c|}
\hline Construct & Related Studies & Explanation \\
\hline $\begin{array}{l}\text { Leadership and } \\
\text { top } \\
\text { management } \\
\text { commitment }\end{array}$ & $\begin{array}{l}\text { (Prajogo and Sohal } \\
\text { 2004) (Prajogo and } \\
\text { Sohal 2006) (Dean } \\
\text { and Bowen 1994) }\end{array}$ & $\begin{array}{l}\text { Degree of visibility and support that } \\
\text { administration presents in implementing a } \\
\text { total value natural environment is important } \\
\text { to the success of TQM adoption. }\end{array}$ \\
\hline Customer Focus & $\begin{array}{lrr}\text { (Black and Porter } \\
\text { 1996) (Evans and } \\
\text { Lindsay } & \text { 1999) } \\
\text { (Hoang, Igel and } \\
\text { Laosirihongthong } \\
\text { 2006) }\end{array}$ & $\begin{array}{l}\text { To have well persuaded customers is the } \\
\text { one of main critical target. Develop and } \\
\text { organize powerful customer relationships } \\
\text { for the longer period. Know the customers' } \\
\text { current needs and future expectations. }\end{array}$ \\
\hline Strategic Planning & (Saravanan R. 2007) & $\begin{array}{l}\text { The degree to which the organization has a } \\
\text { clear vision, operation, long-term design } \\
\text { and value policy. }\end{array}$ \\
\hline $\begin{array}{l}\text { Information and } \\
\text { Analysis }\end{array}$ & $\begin{array}{l}\text { (Hackman and } \\
\text { Wageman 1974) }\end{array}$ & $\begin{array}{l}\text { The degree to which the organization has a } \\
\text { clear vision, operation, long-term design } \\
\text { and value policy. }\end{array}$ \\
\hline $\begin{array}{l}\text { Process } \\
\text { management }\end{array}$ & (Teh 2009) & $\begin{array}{l}\text { Emphasizing supplementing worth to } \\
\text { methods, expanding worth levels, and } \\
\text { having program to decrease trashed time } \\
\text { and costs in all internal methods. }\end{array}$ \\
\hline $\begin{array}{l}\text { Human Resource } \\
\text { Management }\end{array}$ & $\begin{array}{l}\text { (Wilkinson et al. } \\
\text { 1998) }\end{array}$ & $\begin{array}{l}\text { The degree of a wide-ranging management } \\
\text { process that is designed and incorporated in } \\
\text { the firm's strategy. }\end{array}$ \\
\hline
\end{tabular}

(Hoang, Igel and Laosirihongthong 2006) 


\section{Theoretical Framework}

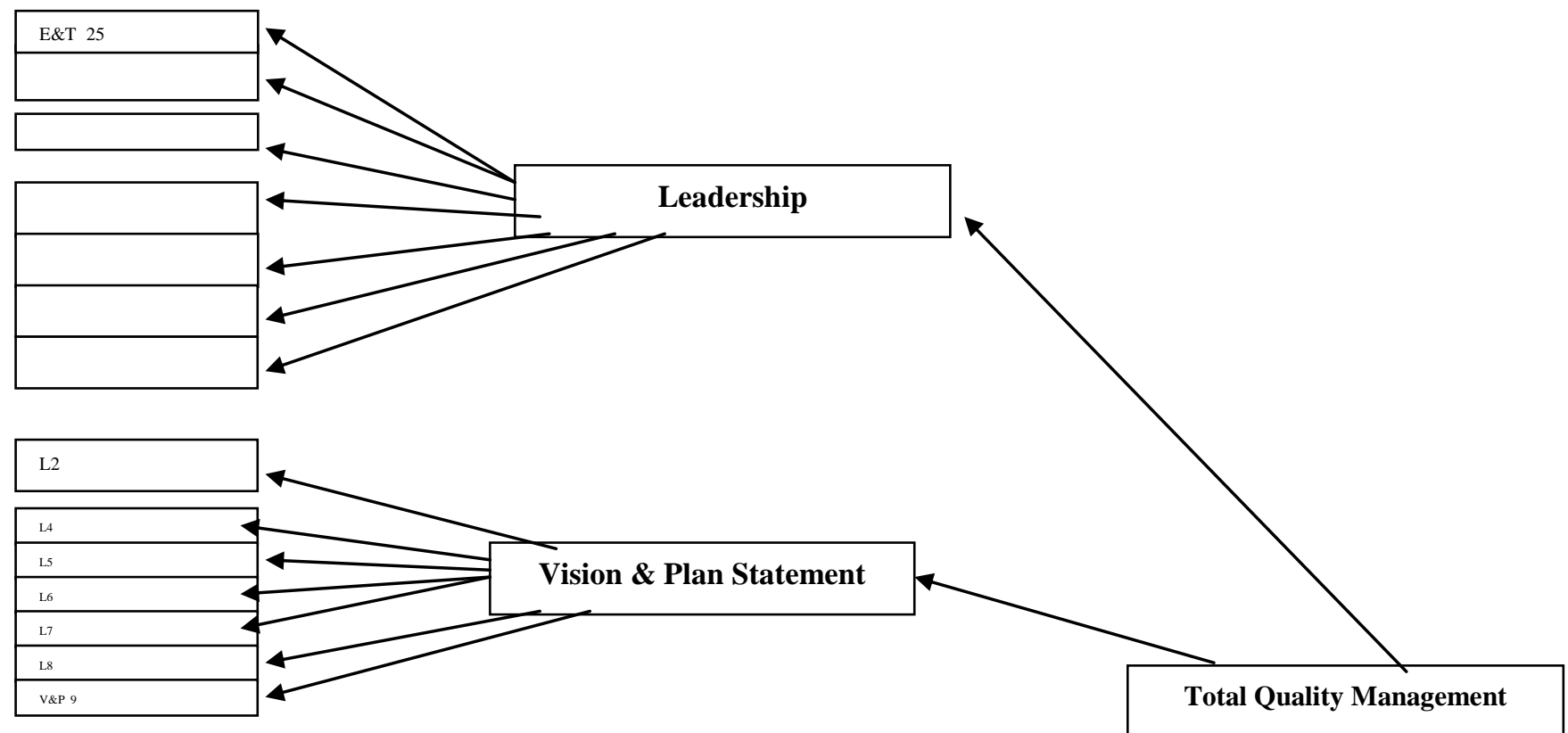

\begin{tabular}{|l|}
\hline V\&P 11 \\
\hline V\&P 12 \\
\hline V\&P 13 \\
\hline V\&P 14 \\
\hline V\&P 15 \\
\hline V\&P 16 \\
\hline E\&P 17 \\
\hline E\&P 18 \\
\hline
\end{tabular}

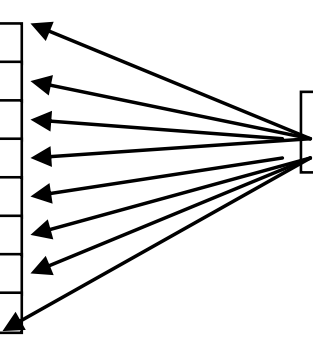

Employee Participation

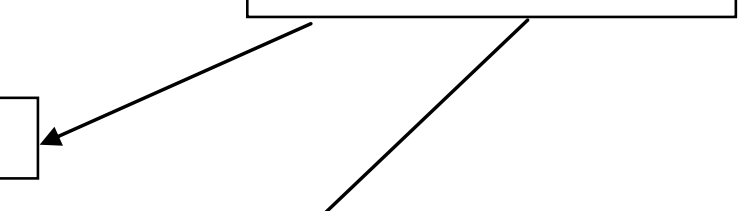

\begin{tabular}{|l}
\hline E\&P 19 \\
\hline E\&P 20 \\
\hline E\&P 21 \\
E\&P 22 \\
\hline
\end{tabular}

E\&P 23 


\section{SCREE PLOT}

Scree Plot further indicates that all the dimensions of relative questions are actually helpful in computing their respective constructs.

\section{Leadership}

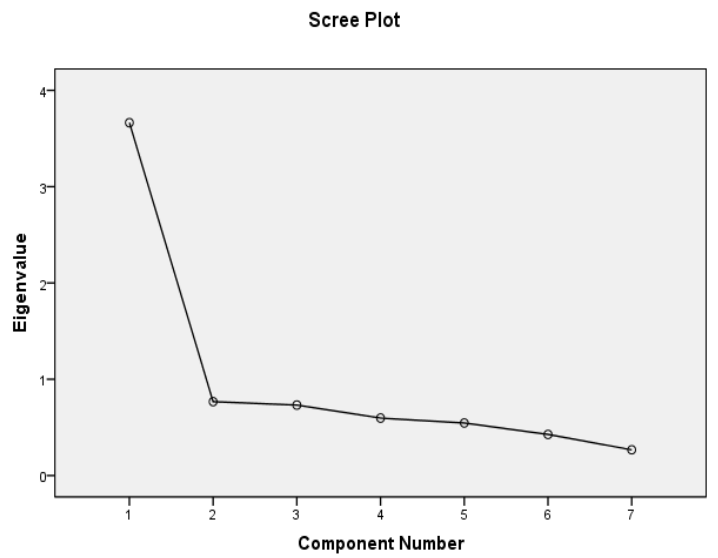

Fig. 2

\section{Employee Participation}

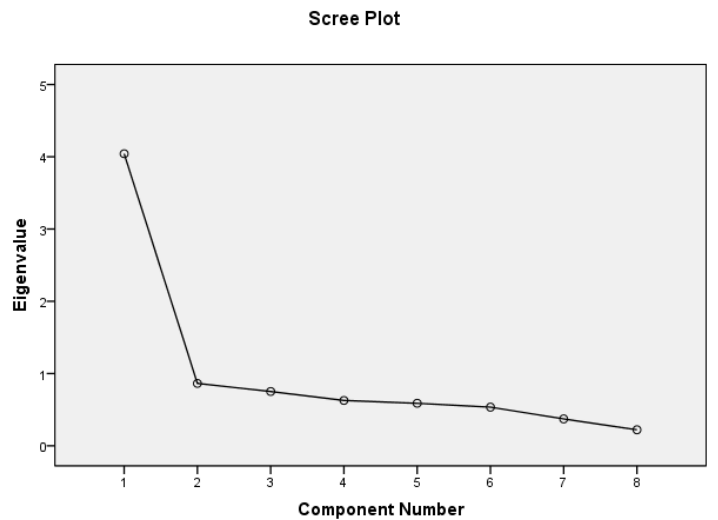

Fig. 4
Vision and Plan Statement

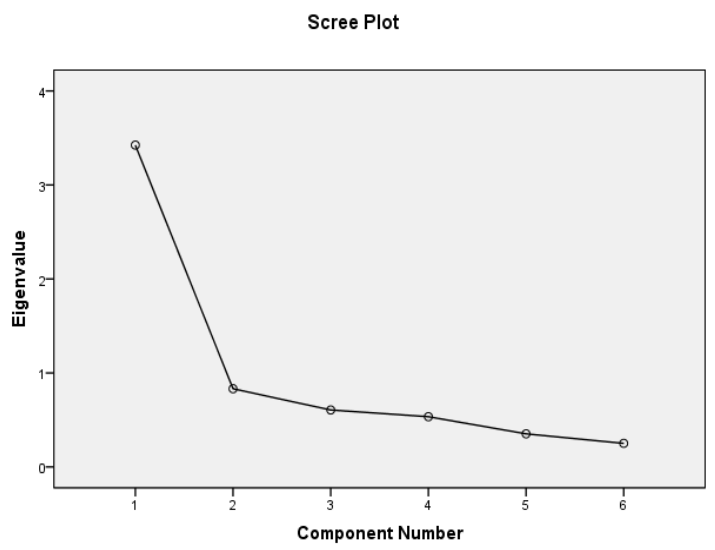

Fig. 3

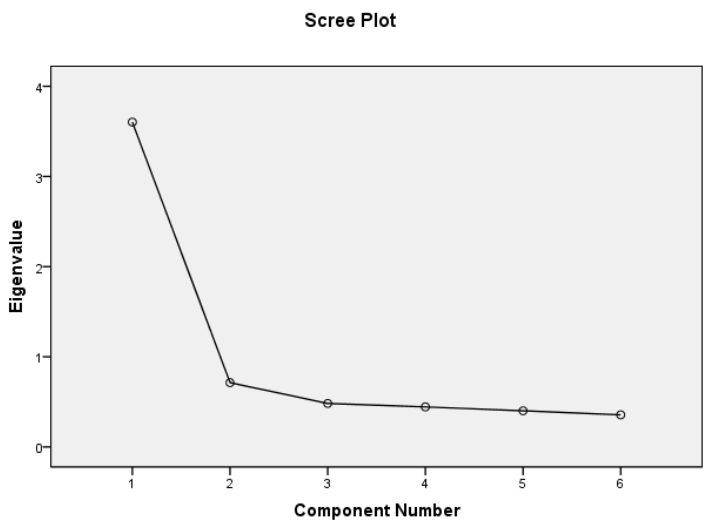

Fig. 5

Eigen values describe the total variance shared by each dimension of a construct. The steep down slope shows that most of variance is explained by this item. The Eigen values in all the constructs are statistically good because there are no multiple steeper curves on $\mathrm{Y}$-axis and no multiple horizontal curves on $\mathrm{X}$-axis. 


\section{Reliability}

Similarly reliability of each constructs is calculated all of them are statistically significant because all of them are above $\mathbf{0 . 7 0}$ (Pallant 2005).

\section{Reliability of all four constructs}

It shows collective reliability of overall constructs. Its value is above 0.70 which shows

\section{Reliability Statistics}

Cronbach's Alpha $\mathrm{N}$ of Items

.769 4

\section{Leadership}

"Leadership data shows that it is statistically significant and reliable. Leadership is checked by 6 questions and Cronobach's alpha value is 0.847 which is more than 0.7 due to which reliability of this construct is ensured.

\section{Reliability Statistics}

Cronbach's Alpha $\quad \mathrm{N}$ of Items

.847 6

\section{Vision and Plan Statement}

Vision and Plan is also reliable. It has 6 dimensions with value of Cronobach's alpha 0.848 which is above 0.70 which means it is statistically significant and reliable.

\section{Reliability Statistics}

\begin{tabular}{lc} 
Cronbach' Alpha & $\mathrm{N}$ of Items \\
\hline $\mathbf{8 4 8}$ & $\mathbf{6}$ \\
\hline
\end{tabular}

\section{Employee Participation}

Employee participation is calculated by 6 questions for checking its Cronobach's alpha value which is .848 and justifies the requirement for reliability which is equal or more than 0.70 .

\section{Reliability Statistics}

Cronbach's Alpha $\quad \mathrm{N}$ of Items

$848 \quad 6$

\section{Education and Training}

The education and training has reliability above 0.70 . It has 6 dimensions and it is found reliable as its value is 0.864 which is statistically reliable and significant. 


\section{Reliability Statistics}

Cronbach's Alpha $\mathrm{N}$ of Items

.864 6

\section{Scatter Plot}

Scatter plot indicates that data is most of the values of these responses are closer to the line of linear regression; it indicates that our model is fit because there is very less differences between the observed values and the model's predicted values. The $\mathrm{R}^{2}$ value should be above 0.10 for model fit and it is seen that $\mathrm{R}^{2}$ value

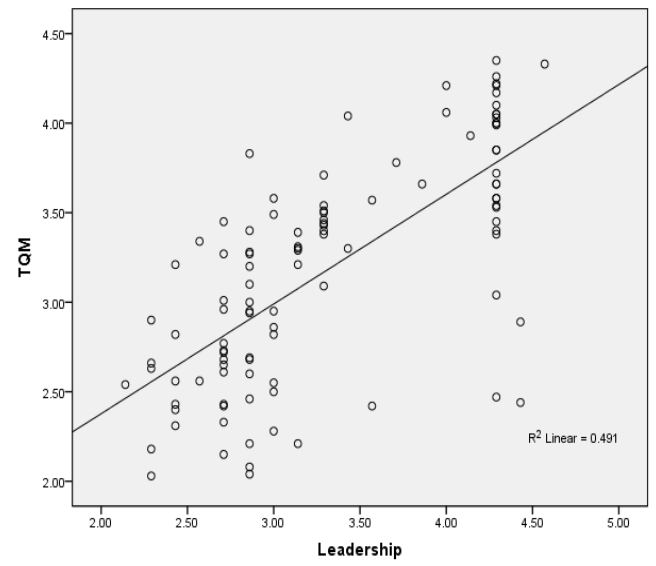

Fig.6

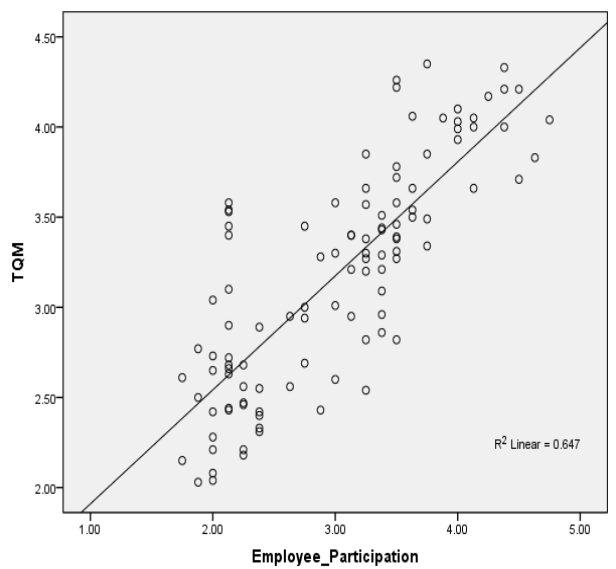

Fig.8.

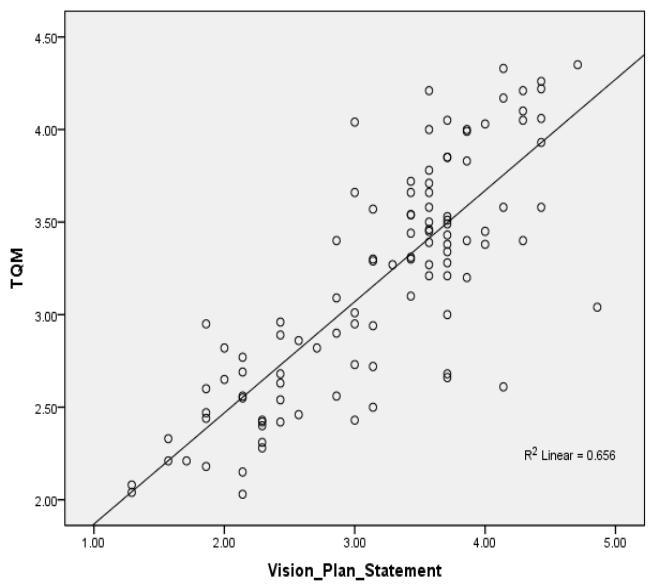

F.g.7

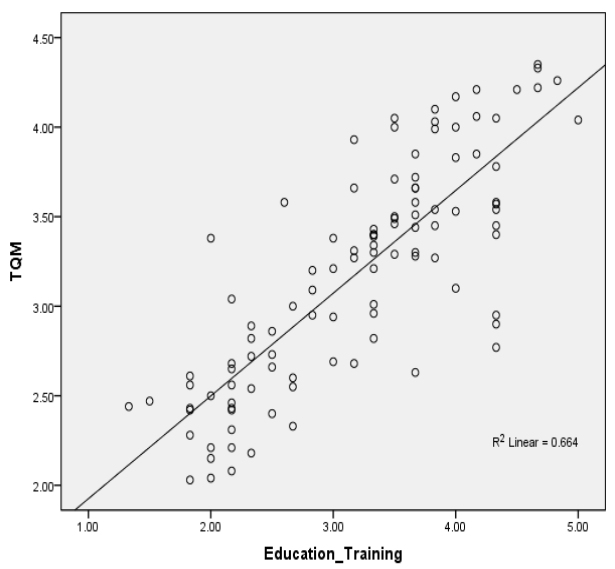

Fig.9

All of the scatter plots have $\mathrm{R}^{2}$ Linear is above 0.10 which mean regression can be run and variable have moderate relationship with TQM Implementation in Petrochemical Sector of Pakistan. 
$\underline{\text { Correlations }}$

\begin{tabular}{|c|c|c|c|c|c|c|}
\hline & & Leadership & $\begin{array}{l}\text { Vision } \\
\text { Plan } \\
\text { Statement }\end{array}$ & $\begin{array}{l}\text { Employee } \\
\text { Participation }\end{array}$ & $\begin{array}{l}\text { Education } \\
\text { Training }\end{array}$ & TQM \\
\hline \multirow[t]{2}{*}{ Leadership } & $\begin{array}{l}\text { Pearson } \\
\text { Correlation }\end{array}$ & 1 & & & & \\
\hline & $\mathrm{N}$ & 106 & & & & \\
\hline \multirow{2}{*}{$\begin{array}{l}\text { Vision Plan } \\
\text { Statement }\end{array}$} & $\begin{array}{l}\text { Pearson } \\
\text { Correlation }\end{array}$ & $.491^{* * *}$ & 1 & & & \\
\hline & $\mathrm{N}$ & 106 & 106 & & & \\
\hline \multirow{2}{*}{$\begin{array}{l}\text { Employee } \\
\text { Participation }\end{array}$} & $\begin{array}{l}\text { Pearson } \\
\text { Correlation }\end{array}$ & $.431^{* *}$ & $.528^{* *}$ & 1 & & \\
\hline & $\mathrm{N}$ & 106 & 106 & 106 & & \\
\hline \multirow{2}{*}{$\begin{array}{l}\text { Education } \\
\text { Training }\end{array}$} & $\begin{array}{l}\text { Pearson } \\
\text { Correlation }\end{array}$ & $.395^{* *}$ & $.546^{* *}$ & $.574^{* *}$ & 1 & \\
\hline & $\mathrm{N}$ & 106 & 106 & 106 & 106 & \\
\hline \multirow{2}{*}{ TQM } & $\begin{array}{l}\text { Pearson } \\
\text { Correlation }\end{array}$ & $.701^{* * *}$ & $.810^{* * *}$ & $.804^{* *}$ & $.815^{* *}$ & 1 \\
\hline & $\mathrm{N}$ & 106 & 106 & 106 & 106 & 106 \\
\hline
\end{tabular}

**. Correlation is significant at the 0.01 level (2-tailed).

Correlation is mutual relationship of two variables. In correlation tables the entire variables are present and the double star sign shows that variables have significant correlation. Leadership is moderately correlated with Vision and Plan Statement, Employee Participation, Education and Training but it is seen that it has strong correlation with TQM equal to $0.701 * *$ which indicates that both Leadership and TQM implementation are very closer to each other. Vision and Plan Statement has moderate relationship with Leadership, Employee Participation and Education and Training but it has strong relationship with TQM implementation which is equal to $0.0801 * *$ which elaborates that Education and Training is very closer to TQM implementation. Similarly, Employee Participation and Education and Training has moderate relationship with rest of the constructs but it is strongly correlated to these variable with correlation results of $0.805^{* *}$ and $0.815^{* *}$ which denotes that these constructs are closer to TQM implementation.

\section{Regression}

A regression of a variable $\mathrm{y}$ on a variable $\mathrm{x}$ is characteristics of the probability distribution of variable $\mathrm{y}$ conditional on $\mathrm{x}$, considered as a function of variable $\mathrm{x}$, this estimate is least-squares fit of sample data on variable $\mathrm{x}$ to data on variable $\mathrm{y}$ (Manski 1991). Researcher has used linear regression model for direct impact of four constructs Leadership, Vision and Plan statement, Employee Participation and Education and Training on TQM implementation. The Linear regression shows direct or positive 
relationship between the TQM implantation and the four constructs of the study. Out of these four constructs, Employee Participation plays most deterministic role in TQM implementation.

\section{Coefficients $^{\text {a }}$}

\begin{tabular}{ll}
$\begin{array}{ll}\text { Un standardized } \\
\text { Coefficients }\end{array}$ & $\begin{array}{l}\text { Standardized } \\
\text { Coefficients }\end{array}$ \\
\hline
\end{tabular}

\begin{tabular}{|c|c|c|c|c|c|c|}
\hline \multicolumn{2}{|c|}{ Model } & $\mathrm{B}$ & Std. Error & \multirow[t]{2}{*}{ Beta } & \multicolumn{2}{|c|}{ T Sig. } \\
\hline \multirow{2}{*}{1} & (Constant) & 1.152 & .207 & & $\mathbf{5 . 5 5 5}$ & .000 \\
\hline & Leadership & .613 & .061 & .701 & 10.016 & .000 \\
\hline \multirow{3}{*}{2} & (Constant) & .575 & .147 & & 3.919 & .000 \\
\hline & Leadership & .349 & .047 & .399 & 7.472 & .000 \\
\hline & $\begin{array}{l}\text { Vision Plan } \\
\text { Statement }\end{array}$ & .455 & .040 & .614 & 11.501 & .000 \\
\hline \multirow{4}{*}{3} & (Constant) & .245 & .094 & & 2.618 & .010 \\
\hline & Leadership & .260 & .030 & .297 & 8.801 & .000 \\
\hline & $\begin{array}{l}\text { Vision Plan } \\
\text { Statement }\end{array}$ & .316 & .027 & .426 & 11.877 & .000 \\
\hline & $\begin{array}{l}\text { Employee } \\
\text { Participation }\end{array}$ & .355 & .027 & .452 & 13.061 & .000 \\
\hline \multirow{5}{*}{4} & (Constant) & .107 & .035 & & 3.090 & .003 \\
\hline & Leadership & .235 & .011 & .268 & 21.702 & .000 \\
\hline & $\begin{array}{l}\text { Vision Plan } \\
\text { Statement }\end{array}$ & .236 & .010 & .318 & 23.143 & .000 \\
\hline & $\begin{array}{l}\text { Employee } \\
\text { Participation }\end{array}$ & .251 & .011 & .319 & 23.400 & .000 \\
\hline & $\begin{array}{l}\text { Education } \\
\text { Training }\end{array}$ & .248 & .010 & .352 & 25.799 & .000 \\
\hline
\end{tabular}

a. Dependent Variable: TQM

TQM Implementation TI= Const. + L. $x_{1}+$ V\&P. $x_{2}+$ EP. $x_{3}+$ ET. $x_{4}$

$$
\mathrm{TI}=0.107+0.235 \cdot \mathrm{x}_{1}+0.236 \cdot \mathrm{x}_{2}+0.251 \cdot \mathrm{x}_{3}+0.248 \cdot \mathrm{x}_{4}
$$

$\mathrm{L} \quad=$ Leadership

$\mathrm{V} \& \mathrm{P}=$ Vision and Plan Statement

$\mathrm{EP}=$ Employee Participation

ET $=$ Education and Training

TQM is based on all these factors (leadership, vision and plan statement, employee participation and education and training). In this study, it is seen that employee participation is most effective construct for TQM implementation. 


\section{Conclusion}

In Petrochemical Sector of Pakistan, the TQM can be implemented but it requires senior management special attention so they can take initiative for TQM implementation. It is a fact that TQM starts from senior management. Petrochemical Sector has a lot of issues i.e. prices instability, lack of funds, risk factor, job instability, costly improvements, less product innovation, huge cost for process innovation, changing demands, effect of substitutes, technological improvement etc. Implementing TQM is not an easy task; it requires strong commitment, education, training, initiative taking, and employee participation in the light of leadership through senior executives. The Petrochemical sector doesn't treat research and development, innovation as their most important priority. The operational performance of this sector can be improved by continuous improvement because one huge investment can't give equal benefits. The companies which follow TQM can get competitive effectiveness. The TQM culture in Pakistani industry is in its emerging stage and it would take some time for better adoption.

\section{References}

1. Abdallah, Ayman Bahjat (2013). The Influence of "Soft" and "Hard"Total Quality Management (TQM) Practices on Total Productive Maintenance (TPM) in Jordanian Manufacturing Companies. International Journal of Business and Management, 8(22), 3-13.

2. Abdullah, M. \& Tari, J. (2012). The Influence of Soft and Hard Quality Management Practices on Performance. Asia Pacific Management Review, 17(2), 177-193.

3. Abdullah, Muhammad Madi Bin \& TARÍ, Juan José (2012). The Influence of Soft and Hard Quality Management Practices on Performance. Asia Pacific Management Review , 17 (2), 177-193.

4. Abdullah, M Madi Bin, ULI, Jegak \& TARI, Juan Jose (2008). The influence of soft factors on quality improvement and performance Perceptions from managers. The TQM Journal, 20(5), 436-452.

5. Anderson, M. \& SOHAL, A. S. (1999). A study of the relationship between quality management practices and performance in small businesses. International Journal of Quality \& Reliability Management., 16 (9), n.k.

6. B Abdullah, M M, Uli, J \& Tari, J J (2008). The influence of soft factors on quality improvement and performance. The TQM Journal, n.k. (n.k.), 436-452.

7. Bemowski, K. (1992). The quality glossary. Quality Progress, 25(2), 18-29.

8. Benner, Marry J. \& tushman, Michel L. (2003). Exploitation, exploration and process management: the productivity dilemma revisited. Academy of management review, 28 (2), 238-256.

9. Black, S. A. \& Porter, 1. J. (1996). Identification of the critical factors of tqm. Decision science, 27(1), 1-21.

10. Brah, S. A., lee, S. L. \& rao, b. M. (1985). Relationship between tqm and performance of singapore companies. International journal of quality and reliability management, 050-070. 
11. Chen, W. H. (1997). The human side of total quality management in taiwan: leadership and human resource management. International Journal of Quality and Reliability Management, 24-45.

12. Chin, Kwai Sang \& Pun, Kit Fai (2001). A proposed framework for implementing TQM in Chinese organizations. International Journal of Quality \& Reliability Management, 272 - 294.

13. Choi, T. Y. \& Eboch, K. (1998). The TQM paradox: relations among TQM practices, plant performance, and customer satisfaction. Journal of Operations Management, 17 (n.k.), 59-75.

14. Christos, Fotopoulos B. \& EVANGELOS, Psomas L. (2009). The impact of "soft" and "hard" TQM elements on quality management results. International Journal of Quality \& Reliability Management, 150-163.

15. Coleman, S. \& Douglas, A. (2003). Where next for ISO 9000 companies? The TQM Magazine, 15(2), 88-92.

16. Conca, F. J., Llopis, J. \& Tari', J. J. (2004). Development of a measure to assess quality management in certified firms. European Journal of Operational Research, 156 (3), 683-97.

17. Corbett, L. M. \& Rastrick, K. N. (2000). Quality performance and organizational culture: a Newzealand study. International Journal of Quality \& Reliability Management, 14-26.

18. Curry, A. \& Kadash, N. (2002). Focusing on key elements of TQM - evaluation for sustainability. The TQM magazine, 14, 207-216.

19. Dean, Jr. J.W. \& bowen, D.E. (1994). Managing theory and total quality: improving research and practice through theory development. Academy of Management Review, 19 (3) , 392-418.

20. Deming, W.E. (1986). Out of Crisis. Cambridge, MA: Massachusetts Institute of Technology Press.

21. Deming, Edward (1998). Out og Crisis. Singapore, MA. Hill.

22. Dessler, G (2003). Human Resource Management. Upper Saddle River,NJ, Prentice-Hall.

23. Ehigie, Benjamin Osayawe \& Akpan, Regina Clement (2004). Roles of Perceived Leadership Styles and Rewards in the Practice of Total Quality Mnanagement. The Leadership \& Organization Development Journal, 25 (1), 24-40.

24. Elzinga, D. J., et al. (1995). Business Process Management:Survey and Methodology. IEEE Transactions on Engineering Management, 24 (2), 119-128.

25. Eng Eng, Q \& Yusof, S.M (2008). A survey of TQM practices in the Malaysian electrical and electronics industry. Total Quality Management \& Business Excellence, 14(1), 63-7.

26. Evans, J. R. \& Lindsay, W. M. (1999). The Management and Control of Quality(4th ed.). Cincinnati, South-Western College Publishing. 
27. Evans, J.R. \& Lindsay, W.M (1995). The management and control of Quality, 3rd edn. New York., West Publishing.

28. Fleishman, E. A. \& Hunt, J. G. (1974). Twenty years of consideration and structure. n.k., Southern Illinois, SI., Southern Illinois University Press, Carbondale, IL (n.k.).

29. Fornell, Claes (1992). A National Customer Satisfaction Barometer: The Swedish Experience. Journal of Marketing, 56 (1), 6-21.

30. Fotopoulos, C. V. (2009.). The Impact of "Soft" and "Hard" TQM Elements on Quality Management Results. International Journal of Quality and Reliability Management. 26(2), 150-163.

31. Fuentes, M. M. F., Montes, F. J. L. \& FERNÁNDEZ, L. (2006). Total Quality Management, strategic orientation and organizational performance: the case of Spanish companies. Total Quality Management \& Business Excellence., 17(3), 303-323.

32. Gadenne, David \& Sharma, Bishnu (2009). An investigation of the hard and soft quality management factors of Australian SMEs and their association with firm performance. International Journal of Quality \& Reliability Management., 26 (9), 865-880.

33. Garvin, G.A. (1991). How the Baldrige Award Really works. Harvard Business Review, November-December, 80-93.

34. Garvin, D.A. (1991). How the Baldrige award really works. Harvard Business Review, 69 (6) , 80-95.

35. Glover, J. (1993). Acheiving the organizational change necessary for successful TQM. International Journal for Quality and Reliability Management 10(6), 4764.

36. Gratton, Lynda \& Truss, Catherine (2003). The Three-Dimensional People Strategy: Putting Human Resources Policies into Action. The Academy of Management Executive, 17 (3), 74-86.

37. Hackman, J. \& Wageman, R. (1974). Total Quality Management:empirical, conceptual and practical issues. Administrative Science Quarterly, 40, 309-342.

38. Hackman, J Richard \& Wageman, Ruth (1995). Total Quality Management:Empirical, Conceptual, and Practical Issues. Administrative Science Quarterly, 309-342.

39. Hoang, D. T., IGEL, B. \& Laosirihongthong, T. (2006). The impact of total quality management on innovation: Findings from a developing country. International journal of quality \& reliability management., 23 (9), 1092-1117.

40. Honarpour, Amir, Jusoh, Ahmad \& NOR, Khalil Md (2012). Knowledge Management, Total Quality Management and Innovation: A New Look. Journal of Technology Management and Innovation, 7 (3).

41. Ittner, C. D. \& Larcker, D (1997). The performance effects of process management techniques. Management Science, 43 (n.k.), 522-534. 
42. Juran, J.M. and Gryna, F.M. (1993). Quality Planning and Analysis, 3rd ed.,. New York, NY, McGraw-Hill.

43. Kannan., V. R, et al. (1999). Tools and techniques of quality management: an empirical investigation of their impact on performance. Quality Management Journal, 6 (3), 34-50.

44. Karimi, Yadollah and Abdulkadir, Sharifah Latifah Syed (2012). The Impact of Organisational Culture on the Implementation of TQM: Empirical Study in the Iranian Oil Company. American Journal of Industrial and Business Management., II, 205-216.

45. Kaynak, H (2003). The relationship between TQM practices and their effects on firm. Journal of Operations Management, 21(4), 405-435.

46. Kotter, J.P. (1995). What leaders really do. Harvard Business Review, May-June, 103-111.

47. Kumar, V., et al. (2008). Performance measurement by TQM adopters. The TQM Journal, 20 (3), 209-222.

48. Laohavichien, Tipparat, Cantrell, R. Stephen and Fredendall, Lawrence D. (2011). Leadership and quality management practices in Thailand. International Journal of Operations \& Production Management., 31 (10), 1048-1070.

49. Lee, V. H. and AL., et (2010). A Structural Analysis of the Relationship between TQM Practices and Product Innovation. Asian Journal of Technology Innovation., 18 (1), 73-96.

50. likert, R. (1961). New Patterns of Management. n.k., New York, NY., McGrawHill (n.k.).

51. Lindsay, W M and EVANS, J R (2002). The Management and Control of Quality, 5th ed. South Western, Nashville, TN.,

52. Lippitt, G. (1969). Organizational Renewal. n.k., NewYork, NY, Appleton Century Crofts (n.k.).

53. Mann, R.S. (1992). The Devlopment of a Framework to Assist in the Implementation of TQM, PhD thesis. Liverpool, UK, Department of Inndustrial Studies, University of Liverpool, UK.

54. Mann, Robin and Keheo, Dennis (1993). An Evaluation of the Effects of Quality Improvement Activities on Business Performance. International Journal of Quality and Reliability Management, 29-44.

55. Mann, R. and Kehoe, D. (1995). Factors affecting the implementation and success of TQM. The international journal of quality and reliability management, 12, 1124.

56. Manski, Charles F. (1991). Regression. Journal of Economic Literature, 29 (1), 34-50.

57. Montes, Fco. Javier Llore'ns, Jover, Antonio Verdu and FERNA NDEZ, Luis Miguel Molina (2003). Factors affecting the relationship between total quality management and organizational performance. International Journal of Quality and Reliability Management, 20(2), 189-209. 
58. Mullins, L. J. (1996). Management and Organizational Behavior. n.k., London, Pitman Publishing (n.k.).

59. Najmi, M. and Kehoe, D. F. (2000). An integrated framework for post-ISO 9000 quality development. International Journal of Quality \& Reliability Management, 17 (3), 226-258.

60. Oakland, J. (2000). TQM text with cases. London, Butterworth-Heinemann.

61. Pallant, Julie (2005). SPSS Survival Manual. vol.12. n.k. ed., Crows Nest NSW, Allen \& Unwin. n.k., n.k.

62. Paul, Adler S., et al. (1995). From Project to Process Management: An Empirically-Based Framework for Analyzing Product Development Time. Institute of Operation Research and Management Science, 41 (3), 458-484.

63. Perdermo-Ortiz, J, González-Benito, J. and Galende, J. (2009). An analysis of the relationship between total quality management-based human resource management practices and Innovation. The International Journal of Human Resource Management., 20 (5), 1191-1218.

64. Perdomo-Ortiz, J., González-Benito, J. and galende, J. (2006). Total quality management as a forerunner of business innovation capability. Technovation, 26 (10), 1170-1185.

65. Powel, T. C. (1995).. Total quality management as competitive advantage: A review and empirical study. Strategic Management Journal, n.k. (n.k.), 15-37.

66. Prajo, D. I. (2005). The Comparative Analysis of TQM Practices and Quality Performance between Manufacturing and Service Firms. International Journal of Service Industry Management., 217-228.

67. Prajogo, D. I. and Sohal, A. S. (2004). The multidimensionality of TQM practices in determining quality and innovation performance - an empirical examination. Technovation, 24 (6), 443-453.

68. Prajogo, D. I. and Sohal, A. S. (2006). The relationship between organization strategy, total quality management (TQM) and organization performance-the mediating role of TQM. European Journal of Operational Research, 168(1), 3550 .

69. Prasad, S and Tata, J. (2003). TheRole of Socio-Cultural, Political-Legal, Economic and Educational Dimensions in Quality Management. International Journal of Operations \& Production Management, 23 (5/6), 487-522.

70. Rahman, S (2004). The future of TQM is past. Can TQM be resurrected? Total Quality Management, 125(4), 411-422.

71. Rahman, S. and Bullock, P. (2005). Soft TQM, Hard TQM and Organizational performance. Omega, 33, 73-83.

72. Raja, Waqas, Bodla, Mahmood Ahmad and MALIK, Dr. Shahab Alam (2011). Evaluating the Effect of Total Quality Management Practices on Business Performance: A Study of Manufacturing Firms of Pakistan. International Journal of Business and Social Science, 2 (9), 110-117. 
73. Salman, Al-Shobaki D., Rami, Fouad H. and AL-Bashir, Adnan (2010). The Implementation of Total Quality Management (TQM) for The Banking Sector in Jordan. Jordan Journal of Mechanical and Industrial Engineering, 4 (2), 304-313.

74. Samson, D. and Terziovski, M. (1999). The relationship between total quality management and operational performance. Journal of operation management, Vol 17, 3936-409.

75. Samson, Danny and Terziovski, Mile (1999). The relationship between total quality management practices and operational performance. Journal ofoperations Management 17, 393-409.

76. Saravanan R., et al. (2007). The Impact of Total Quality Service Age on Quality and Operational: An empirical Study. The TQM Magazine, 19 (3), 197-205.

77. Satish, K. and Srinivasan, R. (2010). Total Quality Management and Innovation Performance: An Empirical Study on the Interrelationships and Effects. South Asian Journal of Management., 17 (3), 8.

78. Singh, P. J., et al. (2006). ISO9000 Series of Standards: Comparison of Manufacturing and Service Organizations. International Journal of Quality and Reliability Management, 23 (2), 122-142.

79. Sit, W. Y. (2009. ). TQM and Customer Satisfaction in Malaysia's Service Sector.. Industrial Management and Data Systems, 109 (7) , 957-975.

80. SIT, W. Y. and AL., et (2011). TQM and Service Quality: A Survey of Commercial Banking Industry in Malaysia. International Journal of Services, Economics and Management., 3 (1), 708-791.

81. Smith, H. and Fingar, P. (2003). IT doesn't matter? Business process do. Tampa,FL., Meghan-Kifer Press.

82. Sun, H. (2001). Comparing quality management practices in the manufacturing and service industries: learning opportunities. Quality Management Journal, 8 (2), 53-71.

83. Sun, H., et al. (2004). The trajectory of implementing ISO 9000 standards versus total quality management in Western Europe. International Journal of Quality \& Reliability Management, 21(2), 131-153.

84. Talib, Faisal (2013). An Overview of Total Quality Management: Understanding the Fundamentals in Service Organization. International Journal of Advanced Quality Management., 1 (1 ), 1-20.

85. Teh, P. L. (2009). Does Total Quality Management Reduce Employees Role Conflict? Industrial Management and Data Systems. Vol: 109 (8), 1118-1136.

86. Teh, P. L. (2008.). Does TQM Impact on Role Stressors? A Conceptual Model. Industrial Management and Data Systems. 108 (8), 1029-1044.

87. Terziovski, M, Power, D and Sohal, A S (2003). The longitudinal effects of the ISO 9000 certification process on business performance. European Journal of Operational Research, 146(3), 580-95.

88. Tsang, A. H.C. and Chan, P. K. (2000). TQM implementation in China: a case study. International Journal of Quality \& Reliability Management, 17(2), 144-57. 
89. Tsang, A. H. C., \& Chan, P. K. (2000). TPM implementation in China: a case study. International Journal of..

90. Vouzas, F. and Psychogios, A. G (2007). Assessing managers' awareness of TQM. International Journal of Quality and Reliability Management, 62-75.

91. Vouzas, F.K. and Psyhogios, A.G. (2005). Best practices of selected Greek organizations on their road to business excellence. The TQM Magazine, 17(3), 259-266.

92. Wilkinson, A., et al. (1998). Managing with Total Quality Management: Theory and Practice. London, Macmillan.

93. Winston, Lewis G., Pun, Kit Fai and Terrence, Lalla R.M. (2006). Empirical investigation of the hard and soft criteria of TQM in ISO 9001 certified small and medium-sized enterprises. International Journal of Quality \& Reliability Management, 23(8), 964-985.

94. Zairi, M. , Letza, S. R. and Oakland, J. S. (1994). Does TQM Impact on Bottomline Results? The TQM Magazine, 16(1), 38-43.

95. Zhang, Zhihai, Waszink, Ab and Wijngaard, Jacob, (2000). An Instrument for measuring TQM implementation for Chinese manufacturing Companies. International Journal of Quality and reliability amnagement, n.k. (n.k.), 730-755.

96. Zhou, J. and George, J.M. (2001). When job dissatisfaction leads to creativity: encouraging the expression of voice. Academy of Management Journal, 44(4), 683-96. 